AperTO - Archivio Istituzionale Open Access dell'Università di Torino

\title{
Management of Helicobacter pylori in Piedmont, Italy
}

\section{This is the author's manuscript}

Original Citation:

Availability:

This version is available http://hdl.handle.net/2318/1671127

since 2019-07-30T16:05:07Z

Published version:

DOI:10.23736/S1121-421X.18.02483-2

Terms of use:

Open Access

Anyone can freely access the full text of works made available as "Open Access". Works made available under a Creative Commons license can be used according to the terms and conditions of said license. Use of all other works requires consent of the right holder (author or publisher) if not exempted from copyright protection by the applicable law. 
Title: Management of Helicobacter pylori in Piedmont, Italy

Paper code: Minerva Gastroenterol Dietol-2483

Submission Date: 2018-02-12 18:02:05

Article Type: Review Article

Files:

1) : Manuscript

Version: 1

Description: manoscritto

File format: application/msword

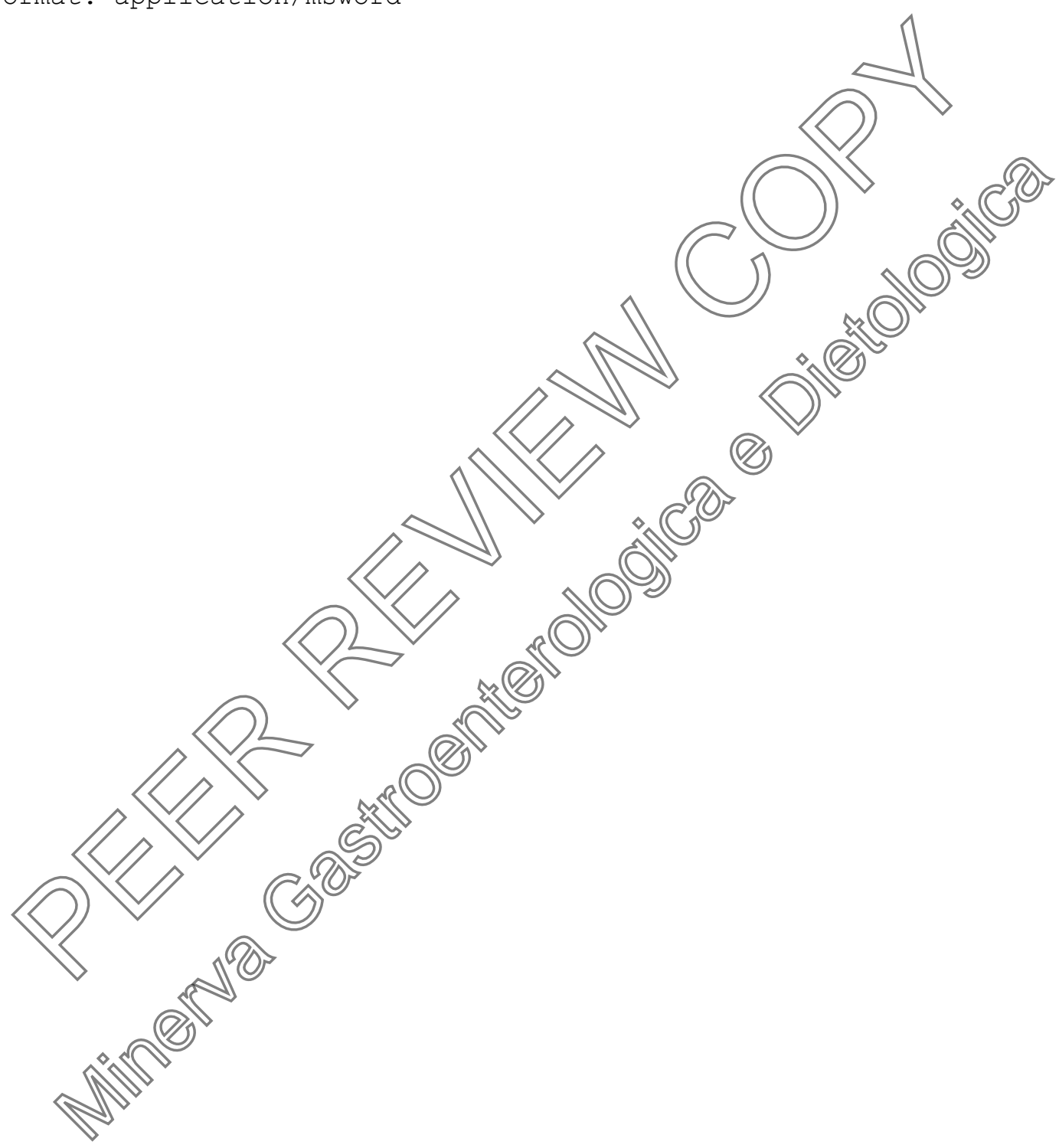




\section{Management of Helicobacter pylori in Piedmont, Italy}

Davide Giuseppe Ribaldone ${ }^{1 *}$, Dario Mazzucco ${ }^{2}$, Sharmila Fagoonee ${ }^{3}$, Lucia Crocellà ${ }^{4}$, Alessandro Lavagna $^{4}$, Mario Fracchia ${ }^{4}$, Gian Paolo Caviglia ${ }^{1}$, Daniele Simondi ${ }^{5}$, Rodolfo Rocca ${ }^{2}$, Marco Astegiano $^{6}$

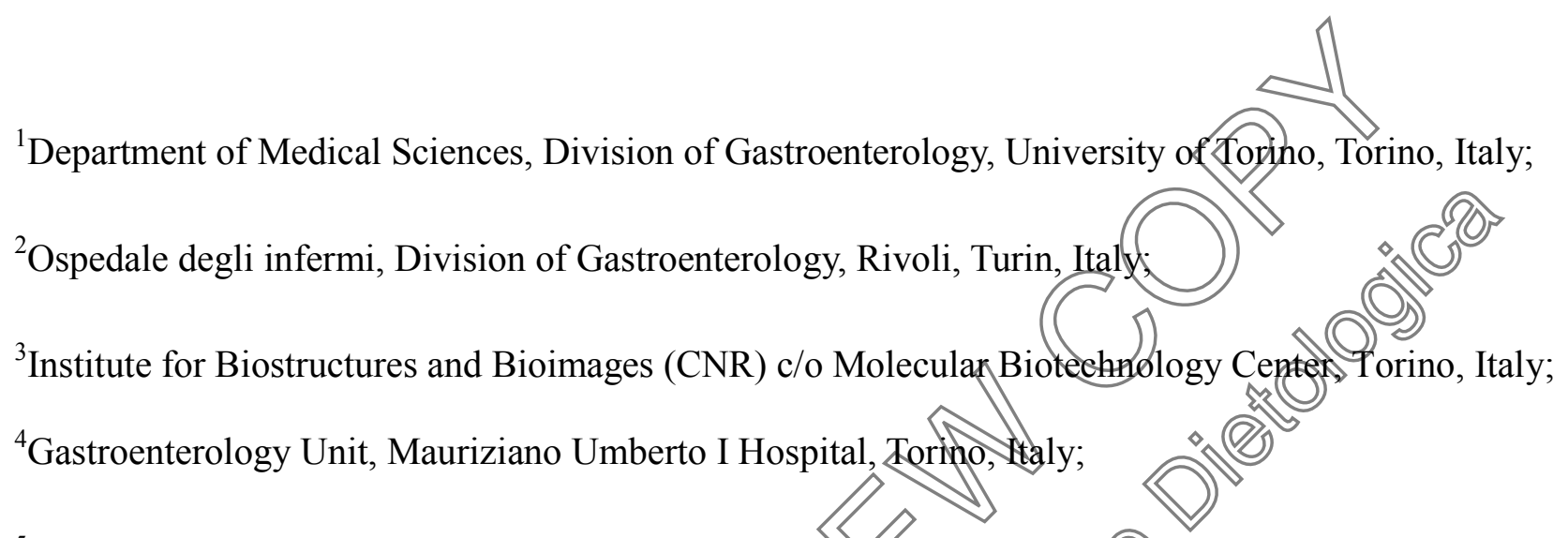

${ }^{5}$ Santa Croce e Carle Hospital, Department of Gastroenterol and DigestiefEndoscopy, Cuneo, Italy;

${ }^{6}$ Department of General and Specialistic Medireine, Gastroenterótogiâ-U, Città della Salute e della Scienza di Torino, Torino, Italy

Conflicts of interest: none to declare.

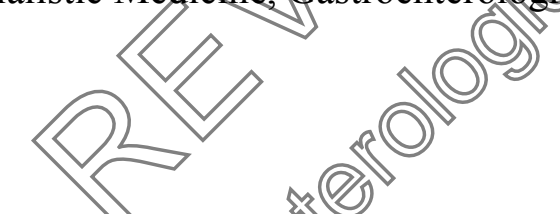

*Corresponding author.Davide Giliseppe Ribaldone - Department of Medical Sciences, Division of Gastroenterology, University g Corino, C.so Bramante 88 - 10126 Torino - Italy. E-mail: davrib_1998@yahoo.comatel: +390116335208, Fax: +390116336752. 


\begin{abstract}
Helicobacter pylori (H. pylori) is a Gram-negative bacterium, usually acquired during childhood,
\end{abstract}

whose natural habitat is the gastric lumen. H. pylori is accepted as the most imperfant cause of gastritis and peptic ulcer in humans. Nevertheless, its important role in the pathogenesis of gastric eancer as well as in several extra-gastroduodenal diseases has been confirmed. The aim of this work to discuss, for the first time in a single article, all publications concerning H. pylori infection arising from Piedmont region, Italy, where in 1893 Giulio Bizzozero was the first who observed and described spiral organisms in the stomach of animal models. A systematic revie@ of all publications on the management of H. pylori in adults in Piedmont, based on a PubMred and a Scopus research from 1965 to 2017 was performed. The discussed aspects are the epedemiology, the study on gastric and extragastric diseases related to $H$. pylori, the diagnostic methods, the treatment of $H$. pylori infection, and the possibility of reinfection. An conclusions with almost 70 publications, Piedmont has proudly maintained the tradition of the father of the Pylori.

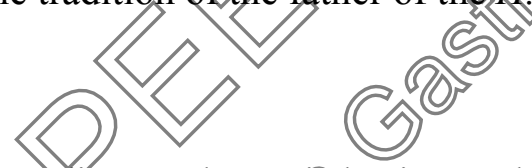

Key words: Cardiovascular - Cogghosis - Culture - Diagnosis - Dyspepsia - Extragastric Diseases Gastritis - Helicobacter - Beptic - Pre-eclampsia - Prevalence - Reinfection - Therapy - Ulcer 
Helicobacter pylori (H. pylori) is a Gram-negative gastric bacterium "re-discovered" by Marshall and Warren in $1983 .{ }^{1}$ Giulio Bizzozero, a former University of Turin' eminent professor, was the first who observed and described spiral organisms in the stomach of dogs and, though he did not realize what actually is known, he considered this finding important enough to publish it in 1893 (B) zzozero could not suspect that this spiral-shaped bacterium will be the most widespreat infectious agent of gastroduodenal diseases. In fact, he could not imagine that his observation 111 spark off an explosion of research, diagnostic tools, and developments of treatment protocolso?

The aim of this "special article" is to do a systematic reviegof all original articles including adult patients managed for H. pylori infection, arising from piedmont (the region of Turin). To identify all appropriate publications, a purmed and a Scopis search of all studies published from 1965 to 31 December 2017 was conductêd. Only originalaticles and letters were included and discussed.

\section{Epidemiology}

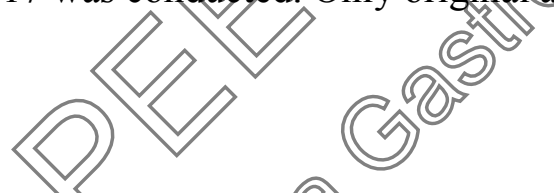

Epidemiology of $H$. pure infection in Piedmont, has been extensively studied in healthy subjects as well as in patients several gastroduodenal or extra-gastroduodenal diseases.

The first study that reported the H. pylori seroprevalence in Turin (Torino), an industrial town in the Northwest of Italy, with a population of almost 1 million people, half of whom were born and lived in the South prior to transfer here, was conducted from April 1995 to July 1995 on 619 consecutive blood 
donors attending the Molinette Hospital's Blood Bank (Turin). H. pylori seroprevalence was assessed by presence of immunoglobulins $\mathrm{G}$ ( $\mathrm{IgG}$ ) against the bacterium in serum, by means of a commercial enzyme-linked immunosorbent assay (ELISA). The overall H. pylori seroprevalence was 47\%: 51\% in males, $27 \%$ in females $(\mathrm{P}<0.001)$. According to the cohort-effect phenomenon, among subjects between 20-29 years of age, the seroprevalence in males was $29 \%$ versus $5 \%$ in females while at $40-49$ years increases to $56 \%$ in males versus $23 \%$ in females and at $50-59$ years was $65 \%$ in males versus $42 \%$ in females. ${ }^{3}$

\section{Gastroduodenal diseases}

Chronic gastritis and peptic ulcer

In a paper published by Di Napoli et al., before treatment all patientsinfected with $H$. pylori had chronic active gastritis. After eradication, the total\$score for gastritis de ereased significantly (from 7.76 to $3.22 ; \mathrm{P}<0.01,95 \% \mathrm{CI}=2.94$ to 5.28 ), white in non-responder the score was only slightly reduced $(6.31 ; \mathrm{P}>0.1, \mathrm{CI}=0.57 \text { to } 3.32)^{4}$

In 1993, the examination of serum samples of 82 drspeptic patients undergoing endoscopy showed that patients with duodenar uleers (DU) hadsignificantly higher systemic IgG responses to a recombinant fragmentyo $128 \mathrm{kD}$ a protein (cytotoxin-associated gene A, CagA antigen) of $H$. pylori than subjects with nomarmucosamgentronic gastritis. ${ }^{5}$

In 1996, Brund et al. enrolled 58 consecutive out-patients with active DU and histology-proven $H$. pylori infection. Upper gastrointestinal endoscopies (EGDS) were performed on entering the study, and then at two, six and twelve months after the completion of the eradicating courses. Eradication produced a significantly higher ulcer healing rate at 2 months and no recurrence at 12 months. ${ }^{6}$

In 1996, Suriani et al. assessed whether H. pylori eradication performed after DU healing, could prevent ulcer relapse during a 2-year follow-up. After confirmation of both DU healing and $H$. pylori 
infection, all patients were randomized to either the treatment or the placebo group and followed up. At the first endoscopy performed 3 months $( \pm 2 \mathrm{SD})$ after antibiotic or placebo treatment, 16 patients $(100 \%)$ in the treatment group and 5 patients $(36 \%)$ in the placebo group were ulcer-free. After a mean 22.6 months (19-27 months), only four patients (25\%) in the treatment group experienced ulcer relapse. In contrast, 13 patients (92.9\%) in the placebo group experienced relapse during follow-up. In this group 11 patients had already had a relapse after 6 months. ${ }^{7}$

In another study, 474 patients suffering from DU were recruited. After therapy endoscopic follow-up provided controls at 6,12 , and 24 months and following controls stoppage in patients with healing $H$. pylori infection and without symptoms. H. pylori infection was yerified histologicall șerologically and, in the last period, with ${ }^{13} \mathrm{C}$ urea breath test (UBT). In patients with DU recirence, the protocol provided, until 1995-1996, the randomized long-term treatment with famotidinge $20 \mathrm{mg} / \mathrm{die}$ or ranitidine $150 \mathrm{mg} / \mathrm{die}$; some patients were treated with seasonal modality. Lateron, the management changed with the use of $20 \mathrm{mg}$ omeprazole on alternate days or lansoprazolet $5 \mathrm{mg} / \mathrm{die}$ for patients who did not benefit from the above treatment. Despite bacterial eradiat)on, in this heterogeneous cohort with multiple causes of gastric damage, on $301 / 474$ (630) did not have DU recurrence or need for longterm PPI assumption. ${ }^{8}$

In a prospective study, Pellicano et al. rinduded 84 patients suffering from bleeding DU associated only with $H$. pylori infection. Afterbacterial eradication the authors observed a recurrence of DU in 3 out of $46(6.5 \%)$ patients whond stopped all medications and in 3 out of 38 (7.9\%) patients under continuous long-term thera with inhibitors of acid secretion. Hemorrhage did not recur during the period of observation in either group. No H. pylori reinfection was observed, as confirmed by the UBT, even in the six patients with DU recurrences. This confirmed that eradication of $H$. pylori is mandatory in patients who had an episode of bleeding from DU. ${ }^{9}$ 
In a prospective study, 41 consecutive patients admitted to the Emergency Care Unit of Molinette Hospital for upper gastrointestinal (GI) bleeding were recruited. Serological diagnosis was performed by measuring antibodies both against $H$. pylori, by a commercial ELISA, and cytotoxic strains (Western Blot for anti-CagA, Vac-A, urease B, urease A). Due to the low sensibility of histology during GI bleeding, the search for $H$. pylori on biopsies was performed only during the follow-up. In case of doubt, either UBT or a stool antigen test were associated. Patients infected by H. pylori were treated, after hemodinamic stabilisation, with a triple therapy regimen inctuding clarithromycin, amoxicillin and omeprazole (CAO). H. pylori eradication was evaluated after ingnths from the end of the therapy with UBT. Sixteen patients were infected from H. pyloritgroup A), 12 hadonty a history of non-steroidal antiinflammatory drugs (NSAIDs) consumption (group B), and (3) patients had both factors (group C). Thus, H. pylori infection was present in 29 out of 41 patients $(71 \%)$. This rate of prevalence was higher than their control population, matched by age, a迎itted to the Emergency Care Unit for other diseases. Furthermore, 20 out of 22 patients (68\% were positive for anti-CagA and antiVacA antibodies. With respect to rebleeding within $72 \mathrm{~h}$, it occurred more frequently in patients with H. pylori infection (groups A and C) than in those witbonly NSAIDs consumption. ${ }^{10}$

\section{Precancerous lesions and gastrye cancer}

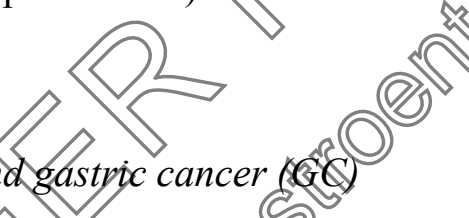

Fifty-four patients with DU and pylori infection received eradication therapy. Endoscopic examination with antral and corpogal biopsy was done at baseline and at yearly intervals. The follow-up period ranged from 60 to 44 months. H. pylori status was determined using a rapid urease test and modified Giemsastain. After H. pylori eradication, glandular atrophy, detected at baseline in 17/24 patients, disappeared in 5, improved in 2 and worsened in 3 cases. In addition, intestinal metaplasia (IM), presented at baseline in 12/24 patients was undetectable in 2 and persisted in the remaining 10 cases. In the 14 patients in whom $H$. pylori infection persisted, glandular atrophy, disappeared in 2, 
worsened in 2 and appeared in 5 patients. IM, detected at baseline in 1 case, appeared in other 5 cases $(\mathrm{P}<0.01)$. After $H$. pylori eradication, atrophy grading did not show a significant improvement, although there was a general trend toward improvement in responder patients, while IM improved in $5 / 12(41 \%)$ patients and was not detectable in 2 cases. In contrast, IM appeared in 5/14 patients in whom H. pylori infection persisted. The authors concluded that, in a long-term follow-up, H. pylori eradication prevented the appearance of IM, whereas it did not affect glandular atrophy. ${ }^{11}$

Ponzetto et al., in 1996, reported the detection of antibodies anti-CagA of pyloks in 96\% of 51 patients having surgery for GC versus $18 \%$ of the general population (patients admitteg to the Hospital's Emergency Care Department). ${ }^{12}$

Twenty patients with GC and H. pylori negative histology took part to anotherstudy. The control group consisted of $H$. pylori negative subjects, divided in adult patients (9) and asymptomatic children (N: 20) with $H$. pylori negative fecal test. The adult controßsuffered from past $H$. pylori infection, eradicated 10 years earlier, and $\mathrm{DU}$ In this group $\mathrm{H}_{\text {th }}$ pylori negative assessment was performed every year by endoscopy and gastric biopsy specimens (the reason for this interval was not explained). CagA and VacA seropositi ity was 90\% $95 \%$ in GC, $84 \%$ and $84 \%$ in DU H. pylori negative patients, $25 \%$ and $5 \%$ in . pylori negative children, respectively. A significant difference was found between adults and chirdren (P positivity to anti-CagA and anti-VacA, in patients with negativity tof other tests, porbably reflects an H. pylori infection before the appearance of GC, since it has been reported anti-H.pylori. ${ }^{14}$ Similar datere subsequently confirmed by the same group in another study. ${ }^{15}$

In two papers, Surianl et al. prospectively evaluated 2360 patients referred to the Endoscopy Unit of Rivoli Hospital. After exclusion of not eligible patients, a total of 1750 patients were studied by endoscopy and multiple biopsies. Type 3 IM was found in $6.7 \%$; 709 patients had $H$. pylori on 
histological examination. The presence of $H$. pylori was neither correlated to type 3 IM in the antrum $(\mathrm{P}=0.99)$ nor to gastric atrophy $(\mathrm{P}=0.1) .{ }^{16,17}$

In the context of a multicenter survey, a prospective case-control study of patients who had undergone surgery for GC was performed. Among patients, $82 \%$ were seropositive for IgG anti- $H$. pylori compared to $57 \%$ of controls $(\mathrm{P}<0.0001)$. Moreover, $84 \%$ were seropositive for anti-CagA antibody versus $18 \%$ of controls $(\mathrm{P}<0.0001)$. There was no difference between the frequency of $H$. pylori in intestinal type and diffuse type carcinoma. ${ }^{18}$

In a study, conducted in Rivoli and Naples, the authors using the immunohistochemical evalation of 5-methylcytosine (5-MC), assessed the global DNA methylation of gastrie mucosa. The population consisted of 93 patients consecutively referred to the Digestive Endoscopy nt of Federico II University of Naples because of dyspeptic symptoms. ANpatients underwent SDS with eight biopsy specimens, five of which were processed for both histological and in and three for the rapid urease test. Furthermore, serum samples were collected to determine anti- $H$. pylori and anti-CagA antibodies. Forty-one surgical samples (at) GC tissues were obtained at the time of surgery and processed for both histological and immonnohistochemical evaluation. To validate their results, the authors selected 4 cases of $H$. pyloritive chronic atrophic gastritis with IM. Finally, they included 10 dyspeptie patients, enrofred at the Endoscopy Unit of Rivoli Hospital, with history of H. pylori eradieation and followedusendoscopically; these patients had preneoplastic lesions (ie, atrophy and IM) and a family history (first-degree relative) of GC. According to $H$. pylori infection, the 93 dyspeptic patients frome Naples were subdivided into $47 \mathrm{H}$. pylori-negative subjects and $46 \mathrm{H}$. pylori-positive patients, 28 of whom were anti-CagA+. In the H. pylori-negative group, all subjects had normal gastric mucosa with a minimal infiltration of lymphomonocytes in the lamina propria. The $H$. pylori-positive patients were subdivided into two groups: $21 \mathrm{H}$. pylori-positive chronic gastritis, 10 of whom were $\mathrm{CagA}+$, and $25 \mathrm{H}$. pylori-positive chronic atrophic gastritis, 18 of whom were Cag-A+. In 
13/25 H. pylori-positive patients, chronic atrophic gastritis, atrophy was mild and restricted to the antrum, while it was moderate and diffuse to both antrum and angulus in the remaining 12 cases, regardless of the Cag-A status. Considering the evaluation of 5-MC, the authors found a gradual decrease in the global DNA methylation from H. pylori-negative to H. pylori-positive chronic gastritis, H. pylori-positive chronic atrophic gastritis and GC cases. These data suggest that DNA hypomethylation could be implicated in $H$. pylori-related gastric carcinogenesis at an early stage. Furthermore, the 5-MC immunopositivity was negatively correlated with markers implicated in cell cycle control such as Ki-67 and p53. ${ }^{19}$ Global DNA hypomethylation is generally considered one of the hallmarks of cancer cells because the genes vulnerable to abeprant hypermethylation, usually are overlapped by the genes targeted by hypomethylation. ${ }^{20}$ During the 10 -year fortow-up the authors found a progressive decrease in global DNA methylation in patients with ghronic atrophic gastritis, despite the successful H. pylori eradication. The katter, in subjects withpreneoplastic lesions did not halt the gastric carcinogenesis process. ${ }^{19}$

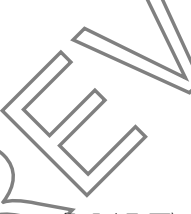

Gastric mucosa-associated lymphoid tissue (MALT) lyomotha

The presence of an organized Jymphoid infiltrate in the lamina propria of gastric mucosa, so-called MALT, is considered an obligate precursor of MALT lymphoma. ${ }^{21}$ In a study published in 1997, the authors followed up 16 patients witthell oligoclonality. Nine of them had Sjogren's syndrome, of which seven had primary and ho had secondary syndrome associated with rheumatoid arthritis and scleroderma (first group Awo additional patients had rheumatoid arthritis, and one scleroderma (second group). Four patients had dyspepsia without an associated autoimmune disease (third group). Patients were followed up for a minimum of 3 months up to a maximum of 33 months (average $15.3 \pm$ 9.2). In 3 out of 12 patients initially positive for $H$. pylori the bacterium had not been eradicated at the time of the last biopsy. Only in one patient did B-cell clonality seemed to parallel H. pylori infection. 
In most cases ( 8 of 10 ) in the 3 groups, clonality persisted for up to 33 months after bacterial eradication. $^{22}$

\section{Other gastrointestinal conditions}

To evaluate the prevalence of $H$. pylori infection in patients with inflammatory bowel disease (IBD) diagnosed for the first time, Pellicano et al. performed a pilot case-control study. Twenty patients were compared to 29 controls affected by idiopathic constipation. All were screenedfor the presence of $H$. pylori by UBT. H. pylori infection was shown in $60 \%$ of patients with IBDversus $41 \%$ amongegntrols $(\mathrm{P}=0.2)^{23}$

In a retrospective case-control study Simondi et al. evaluated the prevalence of topylori infection in patients with celiac disease (CD) or duodenal intraepithetial (ymphocytosis (DUt). One hundred and fifty-four patients with a duodenal biopsy and a diagnosis of damagetype 1, 2, or 3 according to Marsh-Oberhuber classification were inclufted As controls subjects suffering from idiopathic constipation, without CD, were included. A pylori prevalence in CD patients was $36 \%$ versus $19 \%$ in DIL patients and $41 \%$ in controls. Independently etem the other variables considered, H. pylori prevalence in DIL patients was significantly lower compared to controls $(\mathrm{P}<0.05){ }^{24}$

In a single-center stydy, the juclusion criterra were a diagnosis of lymphocytic or collagenous colitis and active $H$. pytori infeesion. The anathors included 50 patients affected by microscopic colitis and in whom $H$. pylori status was assessed by histology (N: 47) or by UBT (N: 3). H. pylori resulted positive in 18 patients (36\%), of 13 affected by lymphocytic colitis and 5 affected by collagenous colitis $(\mathrm{P}=0.51)$. Therewassuno difference in term of $H$. pylori infection comparing cases and controls $(\mathrm{P}=$ 0.59). Nevertheless, considering patients with history of $H$. pylori positivity but with eradication before the diagnosis of microscopic colitis as patients with negative $H$. pylori status, there was a statistically significant difference between cases and controls $(\mathrm{P}=0.006)$. The authors concluded that to be $H$. 
pylori negative, ab initio or after antibiotic treatment, seemed to be a risk factor for the onset of microscopic colitis. $^{25}$

\section{Extra-gastroduodenal diseases}

Since the last decades, several studies have reported on the link between chronic H. pylori infection and a variety of extra-gastroduodenal manifestations, based on potential mechanisms involving a lowgrade inflammatory state, molecular mimicry patterns, and interferences with the absorption of nutrients. ${ }^{26}$ Actually, although the Maastricht V/Florence Consensur Report of the gyropean Helicobacter Study Group has considered causal associations of $H$. pylorjonty those withymexplained iron-deficiency anemia, idiopathic thrombocytopenic purpura (Grade A of recommendation) and vitamin B12 deficiency (Grade B of recommendation) ather relationships could not be excluded. Several studies on this field, have been performed by Piedmont's groups

\section{Heart diseases}
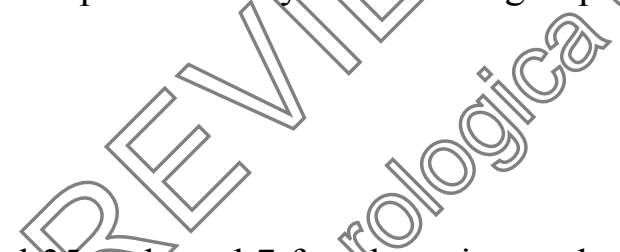

In 1995 Morgando et al. recruited 35 male and 7 fermale patients admitted to the Emergency Unit of Molinette Hospital in Turin acthe myocardial infarction (AMI). They used a commercial ELISA to measure H. pyloris speeific/antibodies the 198 controls were obtained from a cohort of 619 consecutive patients admitred to the game Emergency Unit for other reasons. All 7 AMI patients aged 50-59 years were positive to H. pyori compared with 50\% of controls. However, at age 60 or more the association seemed less strifing (86\% versus $67 \%$ for men, $71 \%$ versus $52 \%$ for women). ${ }^{28}$ The same group confirmed hase findings in a series of studies. ${ }^{29-31}$ In a study performed in Turin and Sondalo (Northern Italy), 223 consecutive male patients admitted for AMI at the Coronary Care Unit were compared with 223 age-matched male patients admitted to the Emergency Care Unit. Cases and controls came from the geographical area of Northern Italy and had a similar socioeconomic status as 
based on occupation and level of education. The seroprevalence of $H$. pylori was significantly higher among patients with AMI $(84 \%)$ as compared to the control population $(62 \%$; $\mathrm{P}<0.0001)$. The antiCagA antibodies were detected in $34 \%$ of the patients versus $27 \%$ of the controls $(\mathrm{P}=0.17) .{ }^{32}$

Pellicano et al. investigated if $H$. pylori infection was associated with unstable angina (UA). Thirtytwo patients consecutively admitted for UA to the Coronary Care Unit of the Novi Ligure and Rivoli Hospitals were included. As controls, the authors selected 64 subjects admitted to the Emergency Care Unit for any reason (excluding cardiological causes), age and sex-matched (2 controls for each case). Cases and controls were from the geographical area of Northwestern Italy and hasimilar socioeconomic status judged on work type and on the level of instpretion. They found trat $81 \%$ of the patients with UA were seropositive, as compared with 53\% anjong the eontrol poruation $(\mathrm{P}=0.007)$. Serum levels of cholesterol, glucose, and fibrinogen in plasma, presenge of hypertension and

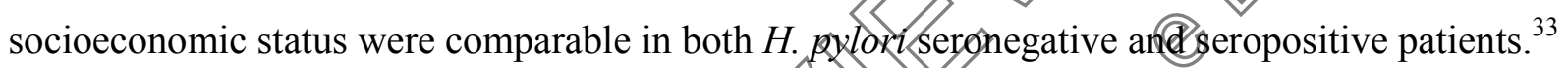

To investigate the possible influence of pylori eradjeation on parameters involved in cardiovascular diseases, 496 patients with 4 - pylori-positive dyspepsia and/or peptic ulcer (DU, N: 80; gastric ulcer, N: 51) were studied un to five years fofter $H$. pylori eradication, a significant trend towards increase for high-density firpoprotein cholsterol (from 48 to $52 \mathrm{mg} / \mathrm{dL} ; \mathrm{P}=0.02$ ) was observed. C-reactive protein (from 0.22 to $0.19 \mathrm{mg} / \mathrm{ar}$ and fibrinogen (from 257 to $222 \mathrm{mg} / \mathrm{dL}$ ) levels decreased in a significantmanner $\left(\hat{p}<0.000 \mathrm{f}\right.$. Body mass index (BMI)(from 25 to $27 \mathrm{~kg} / \mathrm{m}^{2}, \mathrm{P}=0.03$ ) and diastolic blood pressure (from 8 80 to $89 \mathrm{mmHg}, \mathrm{P}=0.04$ ) increased gradually compared to baseline. ${ }^{34}$

In 2014, a multicentestudy including Ponzetto A, reported data on 103 consecutive patients admitted during the year 2005 for ischemic heart disorders. H. pylori infection was determined serologically using an ELISA test and confirmed by western blotting. The latter was also used to detect the presence of anti-CagA antibodies in serum samples. A total of 41 patients $(39.8 \%)$ were $H$. pylori 
positive, and 19 of these (46.3\%) had serum antibody to CagA. B-type natriuretic peptide median levels

in $H$. pylori infected and uninfected patients were $601 \mathrm{pg} / \mathrm{mL}$ and $325 \mathrm{pg} / \mathrm{mL}$, respectively $(\mathrm{P}=0.18)$; median levels in infected CagA+ and CagA- patients were $781 \mathrm{pg} / \mathrm{mL}$ and $305 \mathrm{pg} / \mathrm{mL}(\mathrm{P}<0.01)$.

Interleukin (IL)-6 median levels among infected and uninfected patients were $17 \mathrm{pg} / \mathrm{mL}$ and $7.7 \mathrm{pg} / \mathrm{mL}$

$(\mathrm{P}=0.03)$, respectively. Tumor necrosis factor- $\alpha$ (TNF- $\alpha)$ niedian levels in infected and uninfected patients were 2.9 and 2.5 , respectively $(150.01)^{35}$

\section{Liver diseases}

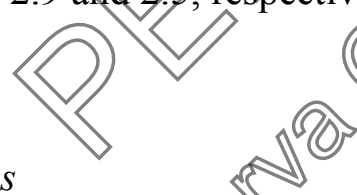

In an initial study on cirrhotic patients, an ELISA method was used to assess the seroprevalence of anti-H. pylori IgG antibodies in 70 consecutive male hepatitis $\mathrm{C}$ virus (HCV) positive cirrhotic patients, and in a control population of 310 male age-matched blood donors from the same area. An immunoblot assay was also used to detect antibodies against the CagA antigen in sera. The prevalences of $H$. pylori 
were $77 \%$ and $59 \%$ in patients and controls $(\mathrm{P}=0.004)$, respectively. Cag-A positivity was observed in $95 \%(57 / 60)$ of the patients versus $18 \%$ of the controls. The authors also analyzed resected liver tissues from 25 hepatocellular carcinomas (HCC): Helicobacter genomic sequences were detected in 23/25 cases (92\%). PCR with primers specific for the conserved region of the cag $A$ gene of $H$. pylori was positive in $81 \%{ }^{36}$ This was the first worldwide report to show Helicobacter sequences in the liver of patients with HCC, published contemporarily with another paper of the Bordeaux' group. ${ }^{37}$

Following this work, the same group showed that the prevalence of antibodies against $H$. pylori in cirrhotic hepatitis B virus patients was significantly higher than in controts $(\mathrm{P}-0.001)$ and $(\mathrm{d} a \mathrm{at}$ there was no relationship between this prevalence and Child-Turcotte-pagh selass. ${ }^{38}$ Simiar pesults was reported considering cirrhotic HCV-positive patients. ${ }^{39}$ On the contrary, the OSeroprevalence of antibodies against $H$. pylori in patients with chronic autorimune hepatitis of sith the formerly known primary biliary cirrhosis, now primary biliary cholangitis, was similar to ifat of controls. ${ }^{41}$

The presence of anti-H. pylori antibodies, enas aluated in 46 consecutive cirrhotic HCV-positive patients and superimposed HCC, attending the Department (at) Gastro-Hepatology, Molinette Hospital of Turin. The prevalence of antibodies to H. pylori significantly higher $(78.2 \%)$ in patients with HCC than $(54 \%)$ in controls 40 oconfirm this 9 initial result, the same group analyzed liver samples obtained during the surgical excision from 23 patients operated upon for HCC superimposed on HCVrelated cirrhosis and from 6 patients setfering from metastatic cancers to the liver, in whom surgery might obtain remission of the disease. The authors found DNA sequences typical of Helicobacter spp. in $85 \%$ livers from patiefs orperated for HCC using Helicobacter genus-specific 16S rRNA primers. Two of 6 liver samples obtained from patients whose livers were resected for metastasis due to colon cancer, contained sequences typical of Helicobacter spp.. Ninety-four percent of liver tissues from positive patients, when tested for Helicobacter genus, were also found positive when tested for the presence of a sequence that was typical for $H$. pylori, i.e., the cag $A$ gene. $^{43}$ 


\section{Neurological diseases}

One hundred three consecutive patients with migraine attending the Headache Center of the University of Turin, for the first visit, were enrolled in a study. A group of 103 healthy subjects attending the Molinette Hospital's Blood Bank, matched for sex and age, served as controls. H. pylori infection was assessed by means of both UBT and IgG against the bacterium in $/$ serum. H. pylori infection was present in $30.1 \%$ of the patients with migraine and $31.1 \%$ of the controls $(P=N S)$. Morevover, this infection was not associated with any significant variationim the clinical featuress of the disease. $^{44}$

Eighty consecutive patients aged less than 65 years, suffering from isehemic str $\mathbb{R e}$ presenting to the Neurological Ward of three Hospitals in Turin were recruited. Sex and age-matched blood donors (4 controls for each case) served as controls. H. pyloxi infection was dem@instrated in $80 \%$ of patients as compared to $59.4 \%$ of controls $(\mathrm{P}<0.001)$. The authors concleded that these results support the association between $H$. pylori infection and stroke. ${ }^{45}$

\section{Metabolism}

Forty-one consecutixy type 2 diabetic sûbects attending an out-patient clinic in Turin participated in a study. Thirty-one healthy subjects matched for sex, age, and geographical area of residence served as controls. The UBT showed gaspies H. pylori infection in $66 \%$ of diabetics and in $48 \%$ of controls $(\mathrm{P}<$ 0.05). Nevertheless, micr@ingiopathy was significantly more prevalent $(\mathrm{P}<0.05)$ in H. pylori negative patients (85\%) than H. pylori positive patients (48\%). ${ }^{46}$

Twelve patients with primary autonomic failure were studied. The results were compared with those of 31 healthy controls and 31 patients affected by type 2 diabetes without autonomic neuropathy. To assess the presence of $H$. pylori infection, all patients and controls underwent a UBT. H. pylori 
infection was detected in $100 \%$ of autonomic failure patients, in $48 \%$ controls and in $71 \%$ diabetic patients; this difference was significant $(\mathrm{P}=0.02){ }^{47}$

\section{Blood disease and systemic autoimmunity}

Thirty-seven consecutive polycythemia vera (PV) patients, followed at the Hematological Unit of the Institute of Medical Science, were included. Seventy-three controls were selected from consecutive out-patients referred to the Department of Internal Medicine and to the Emergency Department for endoscopic examination, matched to patients (1 patient : 2 controls) forsex and age. Alpatients underwent EGDS with multiple gastric biopsies. The operator was brinded as to whether(the patient had PV or belonged to the control group. Blood samples of patients and controls were obtained for serum anti-CagA and IgG antibody determination. H. pylori infection was more frequent in PV patients $(83 \%)$ than in controls $(57 \%)(\mathrm{P}<0.01)$. The prevalence of ant - CagA antibodes $)$ was also significantly higher in PV patients than in controls $(66 \%$ versus $300, \mathrm{P}-0.01){ }^{48}$

The presence of non-organ-specific autoanfibodies (NOSASwas evaluated in 49 consecutive patients suffering from DU and H. pylori infection (Group and 38 consecutive subjects affected with DU related to the consumption of NSAlDs, but notto the presence of $H$. pylori (Group B) and resident in the same area. A serum sanplefrom eachostient was tested to detect antinuclear (ANA), anti-smooth muscle (SMA), and anti-liver/kidney micerosomal-1 (LKM-1) antibodies. ANA, SMA, and anti-LKM-1 antibodies were present, respecturely, in 10\%, 4\%, and none in Group A. In Group B, ANA was present in 8\%, SMA in 8.9. and anti-LKM-1 in none. The difference was not statistically significant. ${ }^{49}$ A recent study, with smilar design, including patients with gastric ulcer, obtained similar results. ${ }^{50}$

\section{Pregnancy}

A total of 167 serum samples from patients (118 male) with reproductive disorders, seen at two clinics for infertility in Turin and Siena were examined. As controls, sera from blood donors of similar 
range of age and proportion male/female as the patients, living in Turin or Siena (N: 837) were examined. The H. pylori status was determined serologically using two tests, a commercially available ELISA and a Western blotting assay. The authors determined the presence of anti-H. pylori IgG, and that of specific IgA in 11 specimens of follicular fluid, 16 specimens of vaginal secretions, and 28 specimens of semen obtained from some of the above-reported patients chosen at random. Seropositivity for H. pylori was significantly more common in patients than in âge- and gendermatched controls $(49.1 \%$ and $33.5 \%$, respectively, $\mathrm{P}=0.0001) .{ }^{51}$ Despite these results, it is premature to state that the association between $H$. pylori infection and infertility is nof coincidental.

In a very interesting study, pregnant women delivering at the Materna-Fetal Medicing Unit of the University of Turin were recruited. Maternal blood samples pyere collected befo(e) delivery from 47 consecutive pregnant women with diagnosis of pre ectampsia (PE), and from 47 women with uneventful pregnancies, matched for maternal age. Twehty placentas we跑obtained from 10 of the PE pregnancies and 10 of the controls delivered by Cesarean section SSerum anti-H. pylori IgG and antiCagA were assessed. Detection of $H$. pylor DAX was carree out by a nested PCR. The two groups were comparable for maternal age, smoking habitopre-pregnancy BMI, gestational weight gain, treatment with antibiotics and risk faters for P Among PE women, there were significantly more $H$. pylori seropositive subjects $(51 / 1 \%)$ than 1 normal pregnant women $(31.9 \%)(\mathrm{P}=0.03)$. Anti-CagA antibodies were significanty moregentum among PE mothers (80.9\%) than among normal pregnant women (14.9\%) $(\mathrm{QR}, 26.0 ; 95 \mathrm{CI}, 8.19-82.7$; $<$ 0.001). All samples, from each of the placentas tested (cases and control (19) were negative for the presence of $H$. pylori DNA. The association was stronger in cases of $\mathrm{Cag}$ - strains. ${ }^{52}$ This study presents direct evidence of an association between $H$. pylori infection and $\mathrm{PE}$ in Italian. A possible bias could arise from the lacking data of ethnic background of all women. The fact that all placentas were negative for $H$. pylori DNA indicates that the pathogenic mechanism would not be local. This finding, along with the knowledge that $H$. pylori is 
predominantly acquired during childhood and that the infection is lifelong when untreated, elicits the speculation that $H$. pylori positive women may have underlying vascular damage; such subclinical dysfunction might augment the inflammatory changes of pregnancy, thus contributing to the symptoms of PE. CagA + strains are associated with increased TNF- $\alpha$ levels. ${ }^{53} \mathrm{PE}$ is equally characterized by an exaggerated inflammatory response: high leucocyte and neutrophil count, high levels of C-reactive protein and high levels of proinflammatory cytokines, such as TNF- $\alpha .^{54}$ These data fere substantially confirmed by the same group in a subsequent study. ${ }^{55}$

\section{Diagnostic methods}

A total of 125 consecutive patients, either dyspeptic or with a previous history of peptic disease referring to GI Unit of Mauriziano Hospital of Turin, for tenlori assessmentoy means of UBT, were included in a study. Fresh stool specimens were collected wythin 1 we 3 of ${ }^{13} \mathrm{C}-\mathrm{UBT}$. Fecal H. pylori detection was performed by means of a commercially availableditsthat uses polyclonal anti- $H$. pylori antibodies (HpSA). Overall UBT was positive in 40 cases ande degative in 85, while HpSA was positive in 71 cases and negative in 54 . Hence, conflicting results were found in $30 \%$ of subjects; 34 out of 37 cases presented a positive HpSA test in the presence of negative UBT. The discrepancy was mostly found in the group of "treated" patients w While a negative HpSA test correlates well with UBT, a certain degree ofdiscreparcy can be appreciated in the presence of positive results, mainly in subjects evaluated after eradication treatrent. ${ }^{56}$ This confirm the importance to use monoclonal tests when diagnosis of $H$. pylori infeetion is performed with a fecal test. ${ }^{21}$

UBT was administered to 91 patients attending the out-patient clinic of the Department of GastroHepatology (Molinette Hospital, Turin). The presence of antibodies against $H$. pylori was tested both in serum and the saliva. A patient was considered infected when had at least two positive tests (gold standard). Saliva (Simplex ${ }^{\mathrm{TM}}$ H. pylori RAPID test, Analyte Diagnostics, Inc. Hallandale, Florida 
USA) was collected by a sterile absorbent pad placed in the mouth and assayed immediately for $H$. pylori antibodies by an immunochromatographic method. There were 37 out of 91 gold standard positive patients, of which Simplex ${ }^{\mathrm{TM}} H$. pylori RAPID test identified 29. Of 54 gold standard negative test, the salivary test falsely identified 13 as positive. Statistical analysis revealed a sensitivity of $78.3 \%$, a specificity of $75.9 \%$ and an accuracy of $76.9 \% .^{57}$

The first study in Piedmont that analyzed by culture the prevalence of $H$. pylori antibiotic resistance was published by Franzin et al. The methods used were the agar disk diffusion test and E-test, a technique for the quantitative determination of susceptibility to antimierobial agents. Fonty-nine patients were included. All the strains tested were susceptible to moxicittin by both methods. Two strains were resistant to clarithromycin by the disk diffusion test and by E-test,@nd one strain was resistant only by E-test. In this study two strains were found to be clarithremyein-resistant by the disk diffusion method and three by E-test. Resistant pretreathents strains weefound in two patients (5.9\%) and a resistant posttreatment strain in one $(2.9 \%)$, indicating acquired resistance. ${ }^{58}$ In a European multicentre study, including data from Turin, the primary aefor $H$. pylori clarithromycin resistance in Italy (2008-9) in adult patients resulted $26.7 \% .^{59}$

To evaluate if in a clinical setting culture can be performed with a good accuracy, bioptic samples of patients who failed at/east 3 courses of treatment were considered before to made the antibiogram for antibiotic resistance assessment. Out 030 positive patients, culture correctly identified 29 . In 1 case, no growth of micro-organisms as observed for up to 12 days. On the contrary, histology, serology and UBT gave a positive resu用 addition, searching for antibodies against CagA in circulation, the strain of the bacterium was considered more virulent. Among specimens obtained from the control group, bacterial culture accurately identified all negative samples. Statistical analysis revealed sensitivity of $97 \%$, specificity of $100 \%$, and accuracy of $98 \%$ for bacterial culture. Positive and negative predictive 
values were $100 \%$ and $94 \%$, respectively. ${ }^{60}$ Thus, also in a clinical setting this procedure provides a good level of diagnostic accuracy.

In a multicentric study including patients with functional dyspepsia, the authors prospectively evaluated the symptomatic benefit of treatment with a food supplement composed of sodium alginate, carbonate calcium, pineapple, papaya, ginger, $\alpha$-galactosidase and fennel (Perdiges, Bioten Snc, Turin, Italy), after H. pylori treatment. The primary goal was to establish the percentage of patients who continued to abstain from PPI as they waited to carry out the UBT, differentiating between patients who were treated (N: 55) with Perdiges and those who were not (N: 36) Af the patients treated with Perdiges $(100 \%)$ and $86 \%$ of the patients who were not $(\mathrm{P}=0.008$ contunued to abstain from PPI in the period awaiting the UBT. ${ }^{61}$ This could allow to reduce the need for antisecretive drugs.

\section{Treatment of $\boldsymbol{H}$. pylori infection}

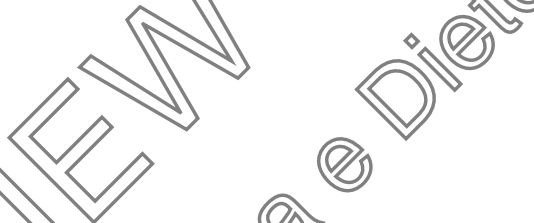

In 1992, Di Napoli et al. treated for 10 days 50 consecutive patients with $H$. pylori positive non-ulcer dyspepsia, with colloidal bismuth subcitrate (CBS), tinidazole and amoxicillin. Infection was confirmed by histological evaluation of four antral biogsy specimens taken during endoscopy, and by a positive urease test. The same evatuations were performed six weeks after treatment. At the second endoscopy 33 patients out of 48 (69\%)gave a negative result to the urea test and there was no histological evidence of $H$ / pylori infection.

Bologna et al. compared the dity of 4 different regimens of CBS in combination with one or two antibiotics to eradicate $H .96$ tori. A total of 140 consecutive patients with histological evidence of $H$. pylori infection on antal biopsies were included in the study. The treatment groups were: a) CBS with amoxicillin and tinidazole b) CBS with ofloxacin c) CBS with ofloxacin and amoxicillin d) CBS with metronidazole. Although higher eradication rates (Table 1) were achieved in group d, the difference did not reach statistical significance. ${ }^{62}$ 
Suriani et al. treated with ranitidine, metronidazole, doxycycline, and CBS for 2 weeks 16 patients with a history of DU healed by $\mathrm{H}_{2}$-receptor antagonist therapy and with $H$. pylori positivity at histological tests: the therapy eradicated $H$. pylori in $81 \%$ of cases. ${ }^{7}$

In another study 126 patients shown infected by $H$. pylori were treated with CAO or MAO (metronidazole $250 \mathrm{mg}$ q.i.d., amoxicillin $500 \mathrm{mg}$ q.i.d and omeprazole $20 \mathrm{mg}$ b.i.d.) regimens for 10 or 14 days. Diagnosis of $H$. pylori infection was assessed by histology and serological evidence of raised levels of IgG against the bacterium at 3, 6, 12, 24 months (Table 1). No statisticaldifference was demonstrated between the two regimens as well as between the two periods.

In 1999, 37 naïve patients with H. pylori positive gastritis were treated with dansoprazole, amoxicillin, plus azithromycin for 3 days starting from the second day of treatmend(table 1). H. pylori eradication rate on per-protocol (PP) basis was $54 \%{ }^{64}$

In the Fanzin' study 10 patients were treated with bismuths salts (CBS240 mg four times a day) and omeprazole (20 mg a day) (CBSO) for 2 weeks. Other 39 subjectsyere treated with the triple therapy CAO for 1 week. PP eradication rate was $90 \%$ (28/31) for 9 atients treated with CAO and $67 \%(4 / 6)$ for patients who received CBSO. ${ }^{58}$

In two studies, patients referred to the Unit of Castroenterology at Mauriziano Hospital (Turin) for the assessment of H. pylori statys were evatuated to analyze eradication rate after treatments prescribed by generalists. The enadication rateg for first-line $H$. pylori eradication therapies adopted by family doctors are reported in Table 1.966

In the study by Rocco@al. 54 consecutive patients with DU and H. pylori infection were treated with $\mathrm{CAO}$ regimen:sixteen patients dropped out during the follow-up, 24 responded to eradication therapy, whereas $H$. pylori persisted in the remaining $14 .{ }^{11}$

A total of 172 patients were randomly treated with a triple therapy regimen comprising proton pump inhibitor (PPI), amoxicillin and clarithromycin: 66 patients received a 1-week triple therapy (group I), 
42 subjects a 10-day triple therapy (group II) and 64 a 14-day triple therapy (group III). H. pylori infection and the outcome of eradication treatment, were assessed by UBT and histology. The overall H. pylori eradication rate was $68 \%$ in group I, $76 \%$ in group II and $72 \%$ in group III, without any statistically significant difference. ${ }^{67}$

A total of 159 patients, with a documented history of recurrent DU, were randomly treated with a triple MAO regimen. In detail, 53 patients received a one-week course (Group I), 53 (subjects a 10-day course (Group II) and 53 others a 14-day course (Group III). H. pylori infectionsyas assessed by UBT and histology. At the end of the course of treatment, the overall H. pylorieradication rate the PP analysis showed no statistical differences, with an eradication rate 6740 ingroup I, 769 in group II and $78 \%$ in group III. ${ }^{68}$

In a randomized study the efficacy of eradication treatrinent, using metronidazole versus tinidazole, in subjects never treated for $H$. pylori, was evaluated Diagnosis and erdication of $H$. pylori infection were assessed by UBT. A total of 171 patients was treated: 910 them with a MAO regimen and 80 with tinidazole, amoxicillin and omeprazole regimen for \&. (1) or 14 days. No difference was found between the two regimens as well as between the two periods. ${ }^{69}$

Reviewing the charts of narive patients underwent UBT in the outpatient clinic of Unit of Gastroenterology of Molinettey Hospital (tith a mean of 2000 test performed per year ${ }^{70}$ ), several interesting data, mere reported. First, Can azithromycin-based triple therapy is not different from a clarithromycin-based triple therapy. ${ }^{71}$ Second, a clarithromycin plus metronidazole-based triple therapy give similar results than triple therapy based on a standard dose of PPI, amoxicillin and clarithromycin or metno- or tinidazole. ${ }^{72}$ Third, the use of amoxicillin plus clavulanic acid-based triple therapy is not different of a CAO regimen. ${ }^{73}$ Fourth, considering a triple therapy based on PPI, amoxicillin and tetracycline, the overall $H$. pylori eradication rate was $53 \%{ }^{73}$ When compared with the amoxicillin plus clarithromycin or plus metronidazole or tinidazole regimens, a significant 
disadvantage was observed versus the metronidazole- $(\mathrm{P}=0.04)$ but not versus the tinidazole- $(\mathrm{P}=$ $0.08)$ and the clarithromycin-based regimens $(\mathrm{P}=0.11) .{ }^{74}$ Fifth, the efficacy of a triple therapy based on ranitidine bismuth citrate, amoxicillin and clarithromycin, is not more effective than a CAO regimen. ${ }^{75}$ Sixth, the efficacy of the ampicillin-based triple therapy for $H$. pylori eradication remains unclear. $^{76}$ Seventh, a one-week PPI, cefixime plus metronidazole based triple therapy gave similar results than a MAO regimen. ${ }^{77}$ Eighth, the success rate of a one-week cefixime plus clarithromycin based triple therapy was not different from that of the $\mathrm{CAO}$ regimen. ${ }^{78}$

In 2015 Ribaldone et al., to asses the change over time of antibiotic effieacy, prospectively exaluated the $H$. pylori eradication rate of consecutive naïve patients, treated for H. pytorn with a standard dose of PPI, amoxicillin $1 \mathrm{~g}$ and clarithromycin $500 \mathrm{mg}$ twice daily. ${ }^{79}$ Furthermore, results @ere compared with the randomized prospective study conducted 10 years earlier with the sameschedule. ${ }^{66}$ Eradication of H. pylori infection was assessed by UBT. The cokort included 182 parents, 99 of them received a 1week regimen (group I) and 83 were treated with a 10-day regingen (group II). The overall H. pylori eradication rate was $71 \%$ in group I and $73 \%$ in group II, Whout significant difference between the 2 regimens. ${ }^{78}$ When compared with the prospective study published in the year 2002, no difference was observed between the groups $\left(\mathrm{P}=0.87\right.$ and of $=0.9$, respectively). ${ }^{69}$ Thus, in Piedmont, a clarithromycin-based treatnentyegimen was equally effective than 10 years earlier. Nevertheless, these eradication rates yere significantly the authors evaluated prospectioy the H. pylori eradication rate of consecutive naïve patients, treated with a triple therapy conprising a standard dose of PPI, amoxicillin $1 \mathrm{~g}$ and metronidazole $500 \mathrm{mg}$ twice daily. The cohon included 39 patients treated with a a 1-week regimen (group I) and 27 treated with a 10-day regimen (group II). The H. pylori eradication rate was $69 \%$ in group I and $70 \%$ in group II $(\mathrm{P}=0.96) .{ }^{80}$ When compared with the prospective study published in the year 2002 no differences were observed in the effectiveness of therapy $(\mathrm{P}=0.81$ for 7 days and $\mathrm{P}=0.95$ for 10 days $) .{ }^{68}$ Thus, in 
Piedmont, a metronidazole-based treatment regimen for $H$. pylori eradication, although unsatisfactory, is as effective as 10 years ago.

Table 1

\section{Relapse and reinfection}

In 1996, Bruno et al. in a cohort of patients with DU in whom H. pylori had been eradicated, showed that reinfection occurred in $14.8 \%$ of patients between month 2 and month 6 , in $5.4 \%$ betweengonth 6 and month 12 , and in $11.1 \%$ between month 12 and month 24 . Active antral gastritis at month 2 was found in $19 \%$ of the patients converting to $H$. pylori positivity at month 6 , but @y in $3.4 \%$ of the patients in whom eradication still persisted at month $6(\mathrm{P}-0.02) .8$ Althoughingited by the tests used ( urease test and histology), this study has the advantage of a pegular follo

In another study, using histology, serolggy and UBT, the authors showed that none of the 108 patients with history of DU, followed up during the averageperiod of 24 months, had a reinfection. Five patients $(4.6 \%)$ had a DU recurence (none duefo NSAIDs). ${ }^{82}$ These findings provided further evidence that the cure of $H$. $x$ rorinfection aldogs for a dramatic reduction in the frequency of DU recurrences, and that the reinfection in actifits is unlikely in their population. The different results of these two studies 81.82 courd be explatged by the potential relapse risk in the former and the exclusion of reinfection in the latter. The robststess of the second is witnessed by the fact that reinfection should be confirmed by the positivito at least two tests.

\section{Conclusions}

In Piedmont, in the last 25 years an intense research on clinical aspects of H.pylori infection has been conducted. Nevertheless, several aspects of basic research have been approached, with the first 
description of Helicobacter sequences in the liver of patients with HCC. The actual practical challenge, based on data of antibiotic resistance, is the application of the Maastricht V/Florence Guidelines, with in Countries with high clarithromycin-resistance rates, as in our region, recommended the bismuthcontaining quadruple therapy as first choice of treatment. ${ }^{27,83}$

\section{References}

1. Warren JR, Marshall B. Unidentified curved bacilli on gastric epithelium înactive chronic gastritis. Lancet 1983;1:1273-5.

2. Bizzozero G. Ueber die schlauchförmigen Drüsen des Magendarnkanals und die Bezi@ìngen ihres Epithels zu dem Oberflächenepithel der Schleimhaut. Arch Mike Anat 1893 (402-82-152.

3. Ponzetto A, Pellicano R, Morgando A, Cirillo D, Marchiaro A, Curti F, et at Seroprevalence of Helicobacter pylori infection among blood donors in Torino, Italy. Sylinerva Gastroenterol Dietol 2001;47:3-7.

4. Di Napoli A, Petrino R, Boero M, Bellis D, Chiandussi L. Quant追ative assessment of histological changes in chronic gastritis after eradication offeletcobacter pylori. J Clin Pathol 1992;45:796-8.

5. Xiang Z, Bugnoli M, Rappuoli R, Covacci A, Ponzetto A, Crabtree JE. Helicobacter pylori: host responses in peptic ulceration. Lancet 1993,341:900-1.

6. Bruno M, Peyre S, Grøss S, Rizzi R, Sategna-Guidetti C. A twelve-month follow-up after Helicobacter pylori eradication. A clinira and histological evaluation. Panminerva Med 1996;38:139-44.

7. Suriani R, Rakzza M, Paltanfere, Mazzucco D, Cardesi E, Colozza M, et al. Helicobacter pylori-positive duodenabulcer: a long-term double-blind randomized study in patients healed with H2-receptor antagenists. Helicobacter 1996;151-4.

8. Vanni E, Pellicano R, Demarchi B, Gardino L, Palmas P, Arena V, et al. Management of duodenal red disease in the era of H. pylori. Minerva Gastroenterol Dietol 1999;45:89-94.

9. Pellicano R, Peyre S, Leone N, Repici A, De Angelis C, Rizzi R, et al. The effect of the eradication of Helicobacter pylori infection on hemorrhage because of duodenal ulcer. J Clin Gastroenterol 2001;32:222-4.

10. Morgando A, Giordanino C, Baronio M, Pellicano R, Rizzetto M. Role of Helicobacter pylori 
infection in peptic ulcer haemorrhage. Minerva Med 2006;97:47-50.

11. Rocco A, Suriani R, Cardesi E, Venturini I, Mazzucco D, Nardone G. Gastric atrophy and intestinal metaplasia changes 8 years after Helicobacter pylori eradication. A blind, randomised study. Minerva Gastroenterol Dietol 2002;48:175-8.

12. Ponzetto A, De Giuli M, Sanseverino P, Soldati T, Bazzoli F. Re: Helicobacter pylori and atrophic gastritis: importance of the cagA status [letter]. J Natl Cancer Inst 1996;88:465.

13. Suriani R, Venturini I, Colozza M, Bona F, Cardesi E, Mazzucco D. Helicobacter pylori antibodies (CagA and VacA) detection. The link between cancer and infection. Minerva Gastroenterol Dietol 2002;48:159-64.

14. Sörberg M, Engstrand L, Ström M, Jönsson KA, Jörbeck H, Granström M. The diagnostic value of enzyme immunoassay and immunoblot in monitoring eradidation of Helicobacter pylori. Scand J Infect Dis 1997;29:147-51.

15. Suriani R, Colozza M, Cardesi E, Mazzucco D, Maring M, Grosso S, et ad CagA and VacA Helicobacter pylori antibodies in gastric cancer. Can J Castroenterol 2008:22:255-8.

16. Venturini I, Taraglio S, Mazzucco D, Camellini L, Cardesi E, Suriani R. Gastric carcinoma risk index, type III intestinal metaplasia and Helicobacter pylori status on antrum and body biopsies in a prospective general population study. Minerva Gastraenterol Dietol 2002;48:169-73.

17. Suriani R, Venturini I, Taraglio S, Mazzucco D, Grosso Ss) Predebon S, et al. Type III intestinal metaplasia, Helicobacter pylori infection and gastice carcinoma risk index in an Italian series of 1750 patients. Hepatogastroenterology 2005285-8.

18. Palestro G, Pellicano R, Fronda GR, Vardente G, De Giuli M, Soldati T, et al. Prevalence of Helicobacter pylori infectron and intestenal metaplasia in subjects who had undergone surgery for gastric adengearcinoma in Nofthwest Italy. World J Gastroenterol 2005;11:7131-5.

19. Compare D, Roeeo A, Liguor. E, D'Armiento FP, Persico G, Masone S, et al. Global DNA hypomethylation is an arfy event in Helicobacter pylori-related gastric carcinogenesis. J Clin Pathol 2011;64:67782.

20. Yoshida T, Yamashita S, Takamura-Enya T, Niwa T, Ando T, Enomoto S, et al. Alu and Sata hypomethyation in Helicobacter pylori-infected gastric mucosae. Int J Cancer 2011;128:33e9.

21. Pellicano R, Ribaldone DG, Fagoonee S, Astegiano M, Saracco GM, Mégraud F. A 2016 panorama of Helicobacter pylori infection: key messages for clinicians. Panminerva Med 2016;58:304-17.

22. Sorrentino D, Ferraccioli GF, Devita S, Labombarda A, Avellini C, Ponzetto A, et al. Gastric 
B-cell clonal expansion and Helicobacter pylori infection in patients with autoimmune diseases and with dyspepsia. A follow-up study. Scand J Gastroenterol 1997;32:1204-8.

23. Pellicano R, Bresso F, Demarchi B, Bertolusso L, Sapone N, Rizzetto M, et al. Prevalence of Helicobacter pylori infection in patients with inflammatory bowel disease: pilot study. Rev Esp Enferm Dig 2010;102:675-6.

24. Simondi D, Ribaldone DG, Bonagura GA, Foi S, Sapone N, Garavagno M, et al. Helicobacter pylori in celiac disease and in duodenal intraepithelial lymphocytosis: Active protagonist or innocent bystander? Clin Res Hepatol Gastroenterol 2015;39:740-5.

25. Ribaldone DG, Simondi D, Astegiano M, Pellicano R. On invers@ association between Helicobacter pylori gastritis and microscopic colitis: The European data. Inflamm Bowel Dis 2016;22:E11-2.

26. Ribaldone DG, Fagoonee S, Hickman I, Altruda F, Sarace GM, Pellicano R. Helicobacter pylori infection and ischemic heart disease: could experimental data lead to clinical studies? Minerva Cardioangiol 2016;64:686-96.

27. Malfertheiner P, Megraud F, O'Morain CA Gisbert JP, Kuipers Es, et al. Management of Helicobacter pylori infection-the Maastrich Plorence Consensuts Report. Gut 2017;66:6-30.

28. Morgando A, Sanseverino P, Perotto C, Mollino F, Gai Venzetto A. Helicobacter pylori seropositivity in myocardial infarktion. Lancet 1995;345 130.

29. Ponzetto A, La Rovere MT, Sanseverino P, Bazzo1if. Association of Helicobacter pylori infection with coronary heart disease. Studyseofirms previous findings. BMJ 1996;312:251.

30. Pellicano R, Mazzarelo NG, Morellonis) S, Allegri M, Arena V, Ferrari M, et al. Acute myocardial infarction and Helicobactepylori seropositivity. Int J Clin Lab Res 1999;29:141-4.

31. Pellicano R, Parravicin PP, Bigi acute nyocardial infarction in northern Italy are often infected by Helicobacter pylori. Panminerva Med 1999; $279-82$.

32. Pellicano R, Parrasicini PP, Bigi R, Gandolfo N, Aruta E, Gai V, et al. Infection by Helicobacter pori and acute myocardial infarction. Do cytotoxic strains make a difference? New Microbiol 2002;25:315-21.

33. Pellicano R, Mazzarello MG, Morelloni S, Ferrari M, Angelino $\mathrm{P}$, Berrutti $\mathrm{M}$, et al. Helicobacter pylori seropositivity in patients with unstable angina. J Cardiovasc Surg (Torino) 2003;44:605-9.

34. Pellicano R, Oliaro E, Fagoonee S, Astegiano M, Berrutti M, Saracco G, et al. Clinical and 
biochemical parameters related to cardiovascular disease after Helicobacter pylori eradication. Int Angiol 2009;28:469-73.

35. Figura N, Palazzuoli A, Vaira D, Campagna M, Moretti E, Iacoponi F, et al. Cross-sectional study: CagA-positive Helicobacter pylori infection, acute coronary artery disease and systemic levels of B-type natriuretic peptide. J Clin Pathol 2014;67:251-7.

36. Ponzetto A, Pellicano R, Leone N, Cutufia MA, Turrini F, Grigioni WF, et al. Helicobacter infection and cirrhosis in hepatitis $\mathrm{C}$ virus carriage: is it an innocent bystander or a troublemaker? Med Hypotheses. 2000;54:275-7.

37. Avenaud P, Marais A, Monteiro L, Le Bail B, Bioulac Sage P, Balabaudg, et al. Detection of Helicobacter species in the liver of patients with and without primary ker carcinoma Cancer. 2000;89:1431-9.

38. Ponzetto A, Pellicano R, Leone N, Berrutti M, Turrini f, Rizžetto M. Hetigobagucter pylori seroprevalence in cirrhotic patients with hepatitis B vifus infection. Neth. (Ned. 2000;56:20610.

39. Pellicano R, Leone N, Berrutti M, Cutufia MA, Ejorentino M, Rizzetto M, et al. Helicobacter pylori seroprevalence in hepatitis $\mathrm{C}$ virus positive patients with cirrhosis. J Hepatol 2000;33:648-50.

40. Durazzo M, Pellicano R, Premoli A, Bêrrutti M, Leone PSPonzetto A, et al. Helicobacter pylori seroprevalence in patients with antoimmune hepatits. Dig Dis Sci 2002;47:380-3.

41. Durazzo M, Rosina F, Premoli A. Morello Ey Pogonee S, Innarella R, et al. Lack of association between seroprevalence of Helicobactergeris bori infection and primary biliary cirrhosis. World $\mathrm{J}$ Gastroenterol 2004:10:3 1799-81.

42. Leone N, Petlicano R, Brunello pylori seroprevalence in aifunts with cirrhosis of the liver and hepatocellular carcinoma. Cancer Detect Prev 2003837:494-7.

43. Pellicano R, Mazzaferro V, Grigioni WF, Cutufia MA, Fagoonee S, Silengo L, et al. Helicobactefspecies sequences in liver samples from patients with and without hepatocellular carcinoma.

44. Pinessi L, Savi L, Pellicano R, Rainero I, Valfrè W, Gentile S, et al. Chronic Helicobacter pylori infection and migraine: a case-control study. Headache 2000;40:836-9.

45. Ponzetto A, Marchet A, Pellicano R, Lovera N, Chianale G, Nobili M, et al. Association of Helicobacter pylori infection with ischemic stroke of non-cardiac origin: the BAT.MA.N. 
project study. Hepatogastroenterology 2002;49:631-4.

46. Quadri R, Rossi C, Catalfamo E, Masoero G, Lombardo L, Della Monica P, et al. Helicobacter pylori infection in type 2 diabetic patients. Nutr Metab Cardiovasc Dis 2000;10:263-6.

47. Maule S, Lombardo L, Rossi C, Crocellà L, Masoero G, Della Monica P, et al. Helicobacter pylori infection and gastric function in primary autonomic neuropathy. Clin Auton Res 2002;12:193-6.

48. Torgano G, Mandelli C, Massaro P, Abbiati C, Ponzetto A, Bertinieri G, et al. Gastroduodenal lesions in polycythaemia vera: frequency and role of Helicobacter pylori. Br $\mathrm{J}$ Haematol 2002;117:198-202.

49. Pellicano R, Touscoz GA, Smedile A, Berrutti M, Saracco G, Repici A, et al. Prevalence of non-organ-specific autoantibodies in patients suffering from dubdenal ulcer with and without Helicobacter pylori infection. Dig Dis Sci 2004;49:395-8.

50. Astegiano M, Touscoz GA, Caviglia GP, Ribaldone BG, De Angelis Coyre S, et al. Nonorgan-specific autoimmunity in patients suffering from gastric wher with and without Helicobacter pylori infection. Minerva Biotecnologica 2017;29:109-13.

51. Figura N, Piomboni P, Ponzetto A, Gambera L, Lenzi C, VairaD, et al. Helicobacter pylori infection and infertility. Eur J Gastroenterol Hepatol 2002. (44),663-9.

52. Ponzetto A, Cardaropoli S, Piccori E. Rolfo A, Genperost, Kanduc D, et al. Pre-eclampsia is associated with Helicobacter fyldris serøpositivity (in) Haly. J Hypertens 2006;24:2445-9.

53. Perri F, Clemente R, Festa V, DeAmbrosio_ Quitadamo M, Fusillo M, et al. Serum tumour necrosis factor-alpha is mareased in patients with Helicobacter pylori infection and CagA antibodies. Ital J Gastroenterol Hepato 999 ;31:290-4.

54. Teran E, Escudero C., Moya W Gowes M, Vallance P, Lopez-Jaramillo P. Elevated C-reactive protein and pro-inflammatrocytokines in Andean women with pre-eclampsia. Int J Gynec Obstet 2001;75:243-9,

55. Pugliese A, Beltrand T, Todros T, Cardaropoli S, Ponzetto A. Interleukin-18 and gestosis: correlation yith Helicobacter pylori seropositivity. Cell Biochem Funct 2008;26:817-9.

56. Masoero G, lombardo L, Della Monica P, Vicari S, Crocillà C, Duglio A, et al. Discrepancy between Helicobacter pylori stool antigen assay and urea breath test in the detection of Helicobacter pylori infection. Dig Liver Dis 2000;32:285-90.

57. Pellicano R, Vanni E, Palmas F, Astegiano M, Leone N, Fagoonee S, et al. Diagnosis of Helicobacter pylori infection: validation of a commercial non invasive salivary test against urea 
breath test and serology. Minerva Gastroenterol Dietol 2001;47:111-6.

58. Franzin L, Pennazio M, Cabodi D, Paolo Rossini F, Gioannini P. Clarithromycin and amoxicillin susceptibility of Helicobacter pylori strains isolated from adult patients with gastric or duodenal ulcer in Italy. Curr Microbiol 2000;40:96-100.

59. Megraud F, Coenen S, Versporten A, Kist M, Lopez-Brea M, Hirschl AM, et al. Helicobacter pylori resistance to antibiotics in Europe and its relationship to antibiotic consumption. Gut 2013;62:34-42.

60. Pellicano R, Smedile A, Ponzetto A, Berrutti M, Astegiano M, Saracco G, et al. How accurate is the culture of Helicobacter pylori in a clinical setting? An appraisal. Panminerva Med 2005;47:191-4.

61. Pellicano R, Ribaldone DG, Saracco GM, Leone N, De Angelis Arrigoni A, etagrenefit of supplements in functional dyspepsia after treatment of Helicobacter (y) Minerva Gastroenterol Dietol 2014;60:263-8.

62. Bologna E, Stroppiana M, Peyre S, Rizzi R, Sategna-gurdetti C. Heliçolaeter pylori infection: comparison among four different therapentic regimens. Panninerva Med 1992;34:138.

63. Pellicano R, Rizzetto M, Ponzetto A. Eradication of Chelicobacter pylori infection and metronidazole resistance: different resytts in differenteoumtries. Saudi Med J 1998;19:215.

64. Lombardo L, Masoero G, Defra Monica P, Pera (A.) Helicobacter pylori eradication using oneweek low-dose lansoprazole plus amoxyciain and azithromycin: failure of a "promising" association. Ital J Gastroenterel Hepatol $1999 ; 31: 266-7$.

65. Lavagna A, Masoer G, Della Monica P, Lombardo L, Crocellà L, Pera A. Modality of treatment and oxtcome of Helicobcter pylori infection in primary care. An Italian experience. Minerya Gastroenterol Diefor $2002 ; 48: 151-4$.

66. Della Monica P, Lavagna,A, Masoero G, Lombardo L, Crocellá L, Pera A. Effectiveness of Helicobacter pylorisadication treatments in a primary care setting in Italy. Aliment Pharmacol Ther 2002;16:1269-75.

67. Palmas F, Peulicano R, Massimetti E, Berrutti M, Fagoonee S, Rizzetto M. Eradication of Helicobacter pylori infection with proton pump inhibitor-based triple therapy. A randomised study. Panminerva Med 2002;44:145-7.

68. Pellicano R, Palmas F, Ponzetto A, Astegiano M, Smedile A, Morgando A, et al. Decreasing eradicaton rate of Helicobacter pylori infection with metronidazole-based triple therapy. A 
randomised study. Minerva Gastroenterol Dietol 2002;48:265-70.

69. Berrutti M, Pellicano R, Astegiano M, Smedile A, Saracco G, Morgando A, et al. Helicobacter pylori eradication: metronidazole or tinidazole? Data from Turin, Italy. Minerva Gastroenterol Dietol 2008;54:355-8.

70. Pellicano R, Bonardi R, Smedile A, Saracco G, Ponzetto A, Lagget M, et al. Gastroenterology outpatient clinic of the Molinette Hospital (Turin, Italy): the 2003-2006 report. Minerva Med 2007;98:19-23

71. Pellicano R, Astegiano M, Smedile A, Saracco G, Berrutti M, Strona S, eftal. Efficacy of azythromicin-based triple therapy for Helicobacter pylori infection: a retrospective study. Panminerva Med 2008;50:259-60.

72. Berrutti M, Fagoonee S, Strona S, Astegiano M, Morgando A, Rizzetto M, et ah Efficacy of clarithromycin plus metronidazole-based triple therapy for Helicobacter pylog eradication: a retrospective study. Minerva Med 2010;101:457-8.

73. Berrutti M, Astegiano M, Smedile A. Fagoonee S. R Rizzetto M, Reificano R. Efficacy of amoxycillin plus clavulanic acid-based triple therapy for Helicobaeter pylori eradication: a retrospective study. Panminerva Med 2010;52:361-2.

74. Pellicano R, Fagoonee S, Astegiano Morgando A, Cisaro F, Rizzetto M. Amoxycillin plus tetracycline as first-line Helicobacter pylori treatment flimerva Med 2011;102:169-70.

75. Cisarò F, Astegiano M, De Angells C, Saracco G.Rizzetto M, Pellicano R. Ranitidine bismuth citrate in the first-line of Helicobacter pyloriratment. Panminerva Med 2011;53:138.

76. Fagoonee S, Pellicano R. Ampicillingased therapy for Helicobacter pylori eradication. Panminerva Med $201 \hat{x} ; 53: 261$.

77. Adriani A, Astegiano M, Smedi⿻ A, Rizzetto M, Pellicano R. Efficacy of cefixime plus metronidazole therapy for Heticobacter pylori eradication: a retrospective study. Minerva Med 2013;104.495-6.

78. Fagoonee S, Astegiang M, Smedile A, Pellicano R. Efficacy of cefixime-based triple therapy for Helicobactepylori eradication: a retrospective study. Panminerva Med 2013;55:309-10.

79. Ribaldone De, Fagoonee S, Astegiano M, Saracco G, Pellicano R. Efficacy of amoxycillin and clarithromycin-based triple therapy for Helicobacter pylori eradication: a 10-year trend in Turin, Italy. Panminerva Med 2015;57:145-6.

80. Ribaldone DG, Astegiano M, Saracco G, Pellicano R. Amoxycillin and metronidazole therapy for Helicobacter pylori eradication: A 10-year trend in Turin, Italy. Balkan Med J 2017;34:290- 
1.

81. Bruno M, Peyre S, Grosso S, Sategna-Guidetti C. Reinfection or recrudescence after apparently successful eradication of Helicobacter pylori infection: can the type of gastritis solve the problem? Ital J Gastroenterol 1996;28:216-9.

82. Pellicano R, Palmas F, Arena V, Demarchi B, Leone N, Rizzetto M, et al. Lack of reinfection after Helicobacter pylori eradication in duodenal ulcer disease: A prospective study from Turin, Italy. Ann Saudi Med 1999;19:376-7.

83. Pellicano R, Ribaldone DG, Fagoonee S, Astegiano M, Saracco GM. The first fline treatment of Helicobacter pylori infection in Piedmont in the year 2017. Panminerva /4ed 2017;59:199.

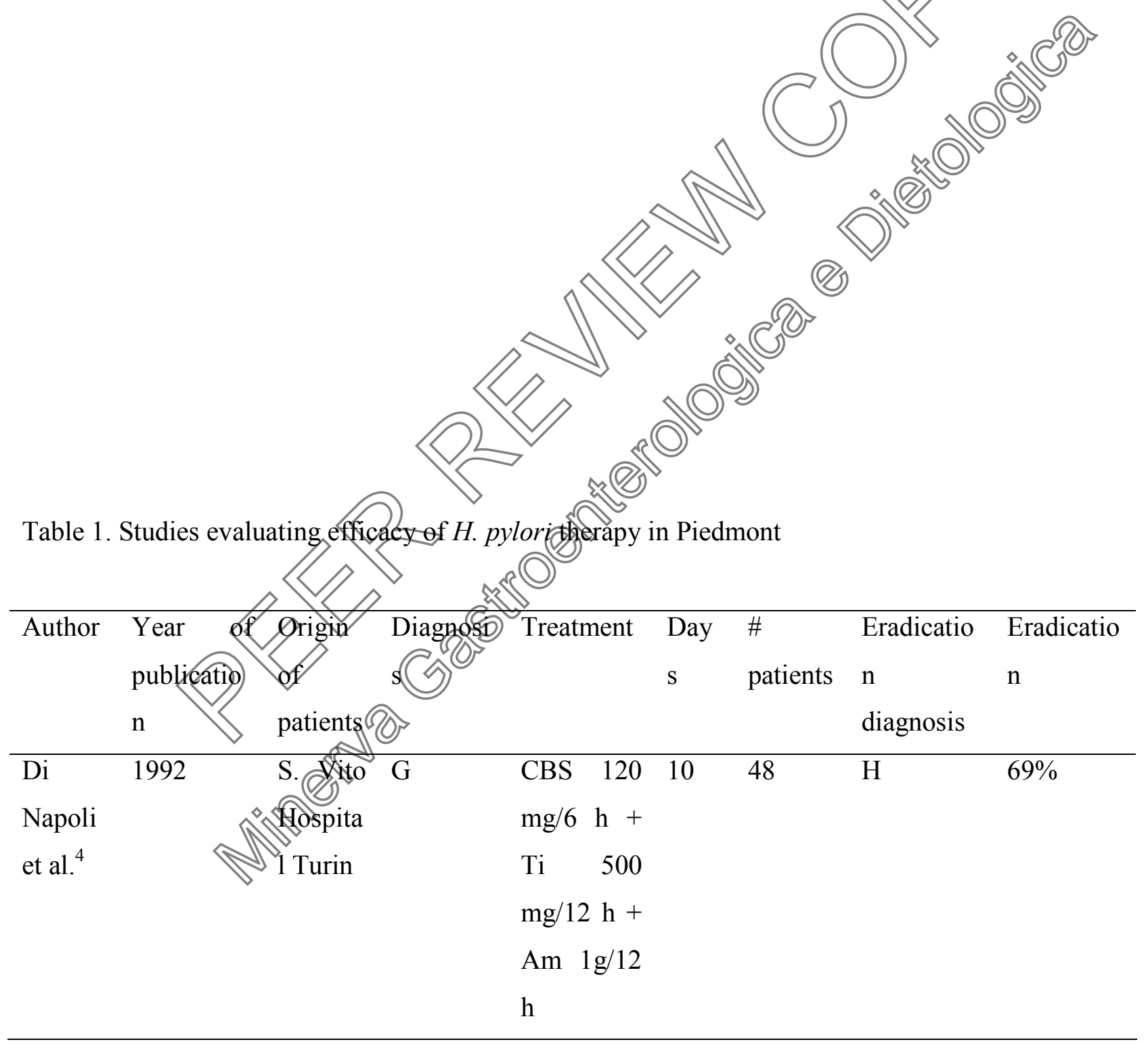




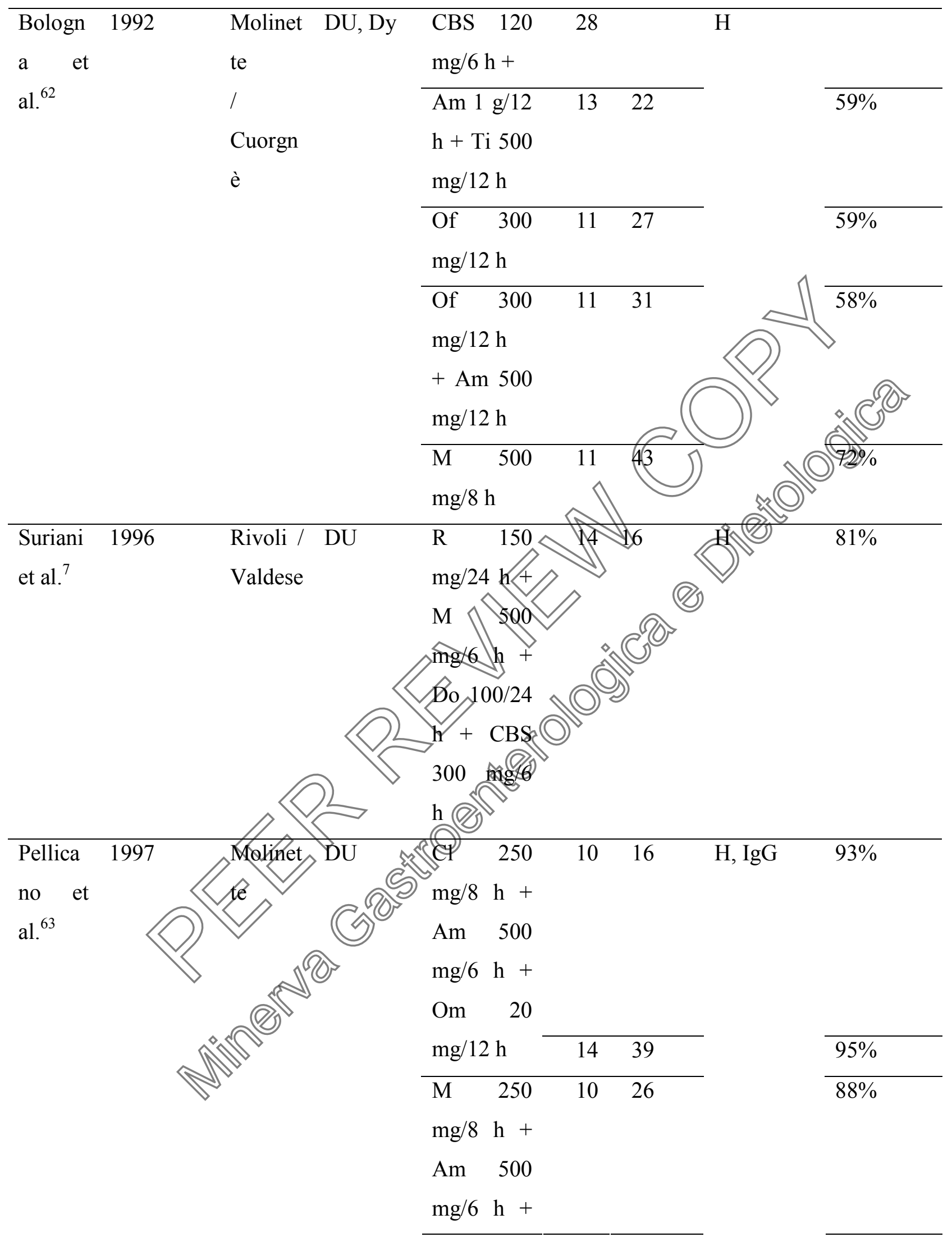




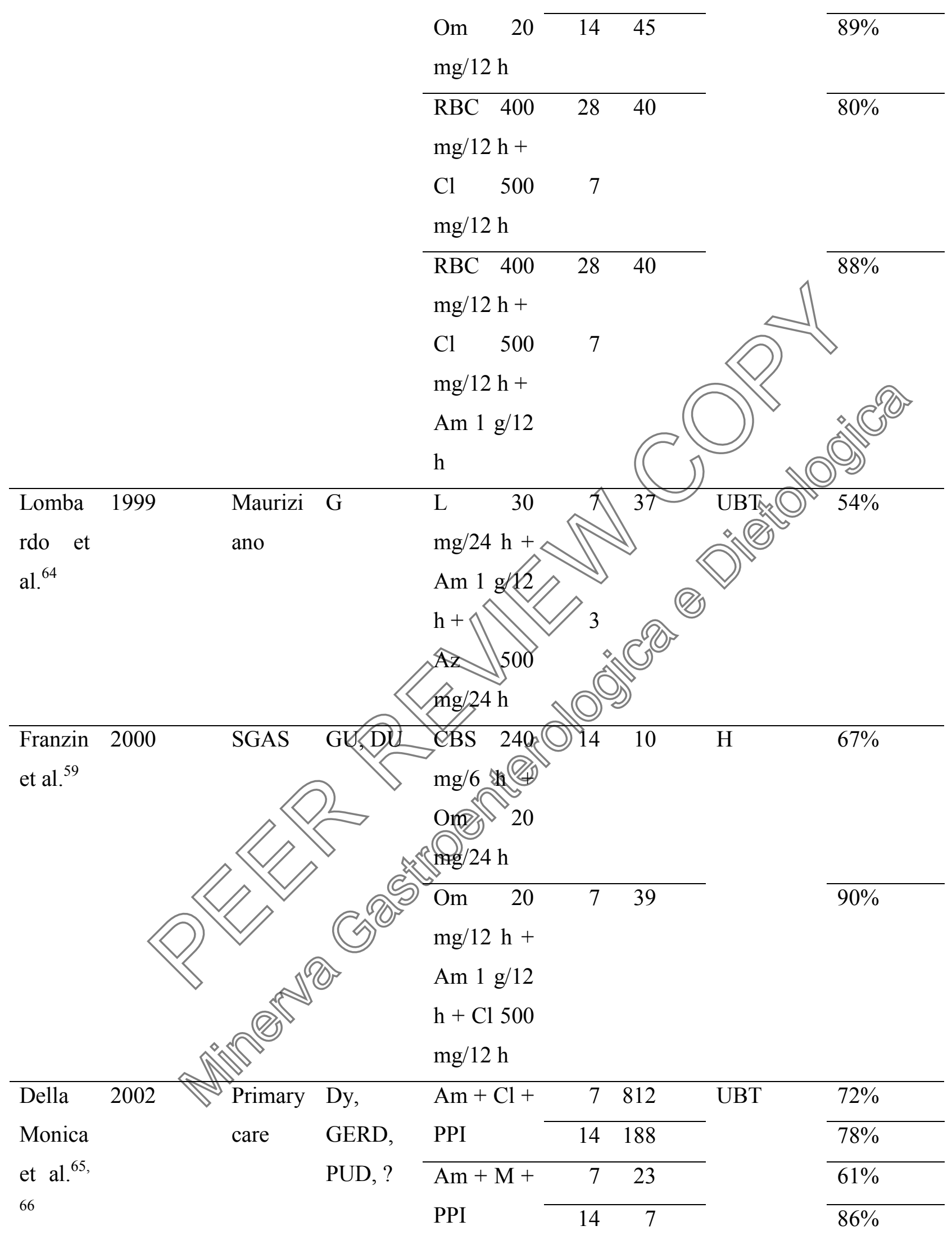




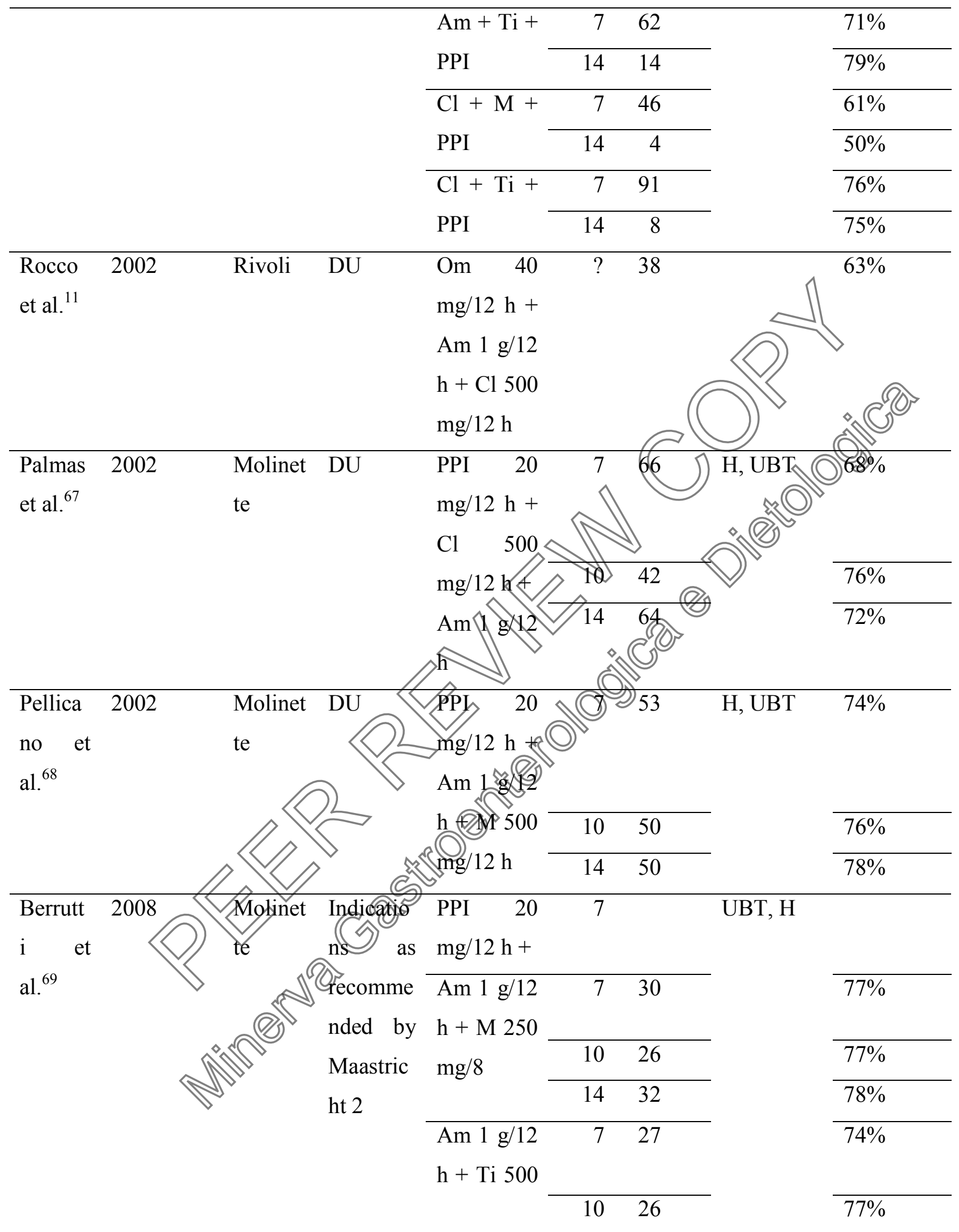




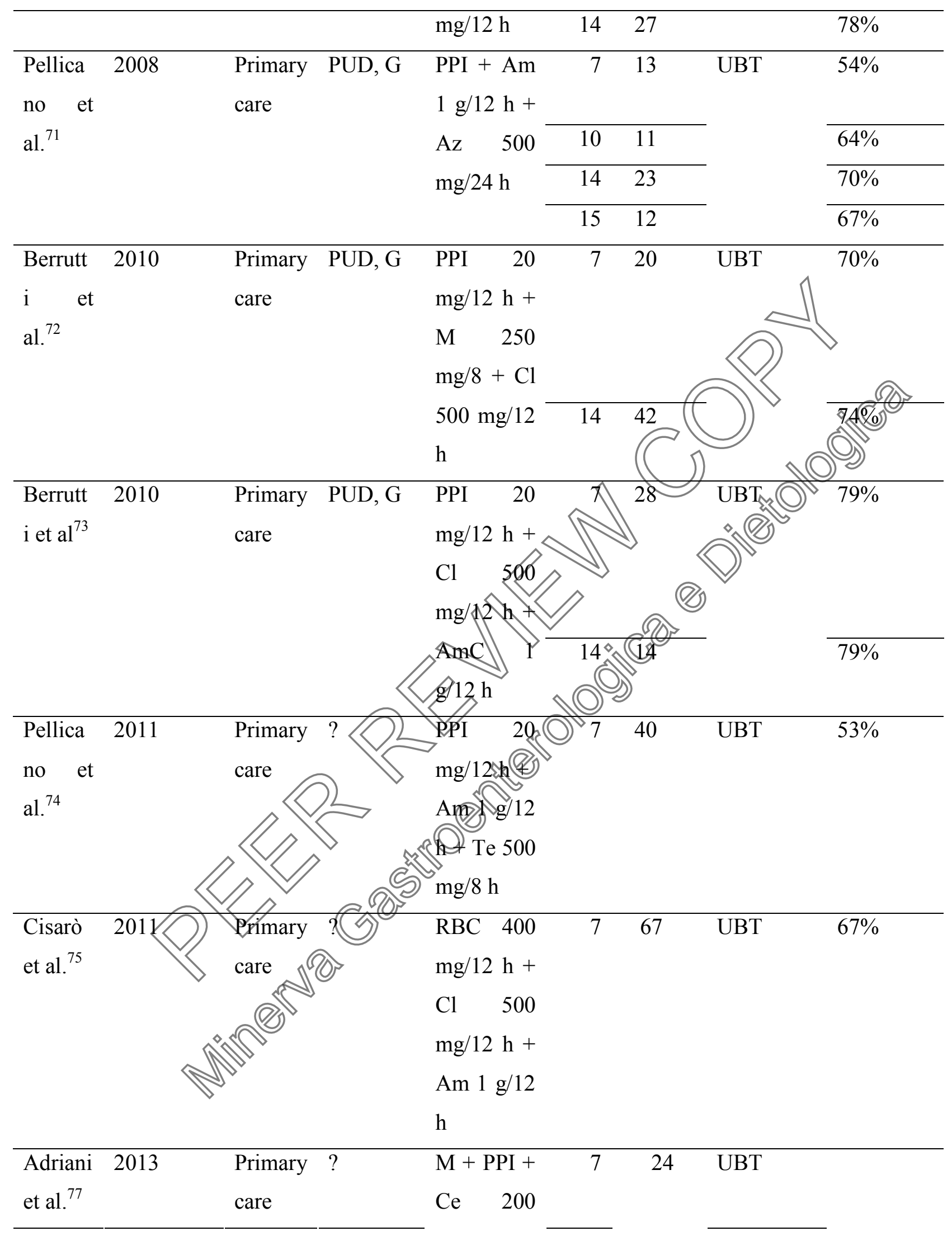




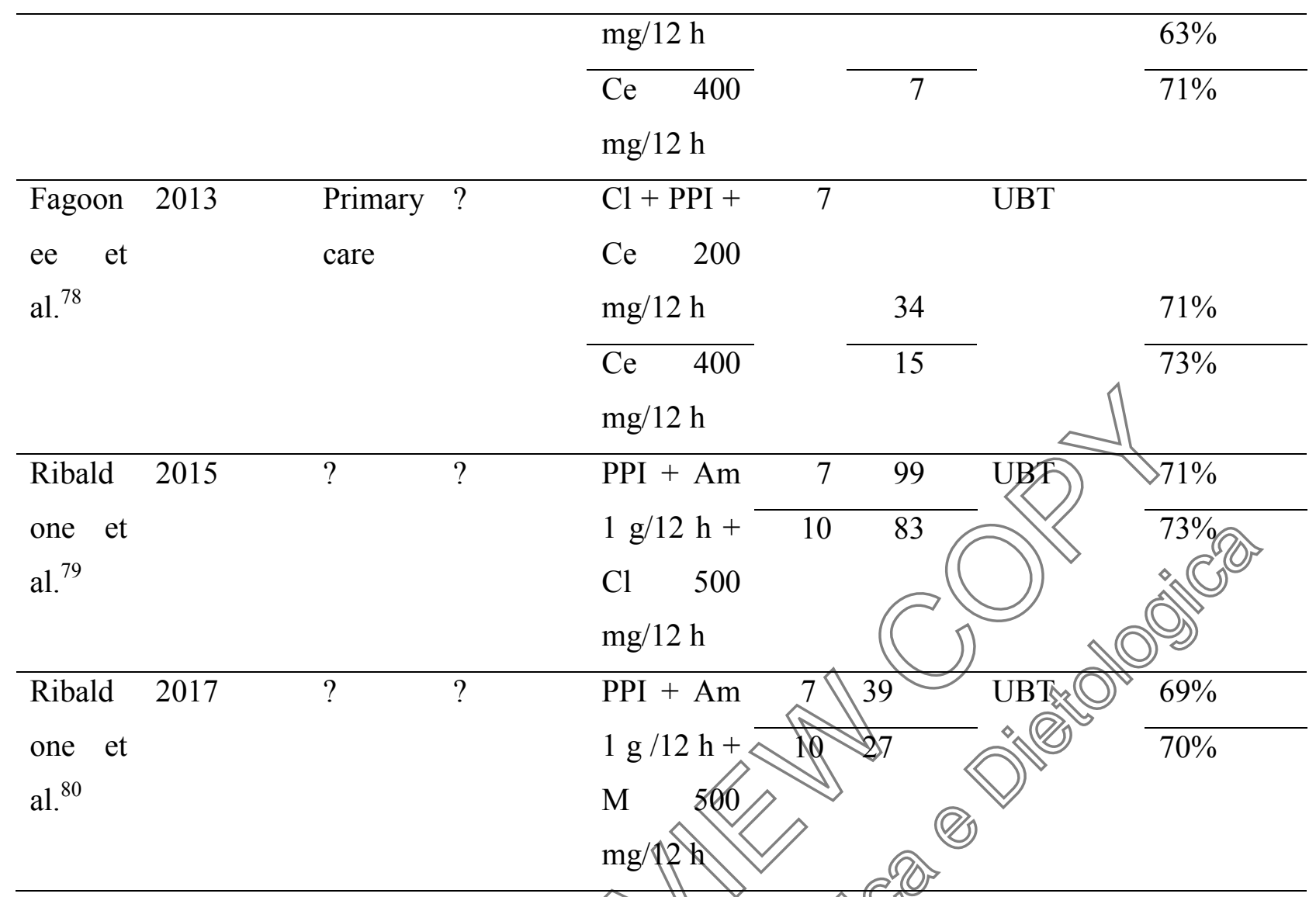

DU, duodenal ulcer; Dy, dyspepsia; CBS, eolloddal bismutĥfubcitrate; Am, amoxicillin; Ti, tinidazole; Of, ofloxacin; M, metronidazole, H, histology ranitidine; Do, doxycycline; Te, tetracycline; F, floxacine; Om, omerazele; G, gastritis, Cll, clarithromycin; IgG anti-H. pylori; PUD, peptic ulcer disease; $D_{n}$ duodenitis; UBR trea breath test; RBC, ranitidine bismuth subcitrate; L, lansoprazole; Az azithromycin:BOH, rapid urease test; $\mathrm{Cu}$, culture; SGAS, San Giovanni Antica Sede; GU, gastric ulcer; PP, Proton Pump Inhibitors; GERD, gastroesophageal reflux disease; ?, unreported, ATB, antiblotic; AmC, amoxicillin and clavulanic acid; Ce, cefixime. 